\title{
E-banking Functionality and Outcomes of Customer Satisfaction: An Empirical Investigation
}

\author{
Dr. Ala 'Eddin Mohd Khalaf Ahmad \\ Assistant Professor, Department of Marketing, Applied Science University \\ P.O. Box 922717, Amman 11192, Jordan \\ Tel: 962-776-829-887 E-mail:aladdin.a.n@hotmail.com
}

Dr. Hasan Ali Al-Zu'bi

Associate Professor, Department of Business Administration, Applied Science University

P.O. Box 922717, Amman 11192, Jordan

Tel: 962-795-629-808Ｅ-mail: zubi1963@yahoo.com

\begin{abstract}
Purpose - The purpose of this paper is to explore the adoption of e-banking functionality and investigates the impact of e-banking on the outcomes of customer satisfaction namely, loyalty and positive WOM within the Jordanian Commercial Banks.

Design/methodology/approach - A purposive sampling technique was employed to recruit 179 customers representing the desired range of demographic characteristics (e.g. gender, age, and computer use), previous internet experience levels and product-related knowledge.

Findings - This research showed that adoption of e-banking (accessibility, convenience, security, privacy, content, design, speed, fees and charges) had a positive effect on Jordanian Commercial Bank customers' satisfaction, loyalty, and positive WOM.

Originality/value - The paper contributes to previous research by adding to existing knowledge regarding what constitutes e-banking service. The paper makes key recommendations towards enhancing current online financial services delivery.
\end{abstract}

Keywords: E-banking, Customer satisfaction, Loyalty, WOM, Jordan

\section{Introduction}

One of the most recent channels of distribution to be used in the financial services organizations is electronic banking; this method was established in the mid 1990s, thereafter steadily becoming more important (Allen et al, 2001). The term electronic banking refers to "the provision of information or services by a bank to its customers, via a computer or television"(Allen et al, 2001). A more developed service is one that provides customers with the opportunity to gain access to their accounts and execute transactions or to buy product online via the internet (Daniel, 1999). Compatible with the revolutionary components of the electronic marketplace, Jordan has actively developed e-banking services since 2004 (Central Bank of Jordan, 2009). Moving towards an industrialization nation with knowledge economy as the backdrop, the personal computer and online approach of life is growing in Jordan. Public awareness of e-banking among users has been increased and thus people are ready to migrate to technology applications. With the population of approximately 6 million in Jordan (General Statistics Bureau, 2009), it is vital for bankers to understand the current usage trend of e-banking system.

Some scholars have shown that many international internet users demonstrate similar behaviors and preferences across nations (Quelch and Klein, 1996). Other researchers have studied the internet in the context of traditional cultures, and yet delimited by national borders (Park and Jun, 2003). Some studies have examined the issues on the evolution of e-banking (Sohail and Shanmugham, 2003) and investigated the success factors in various e-delivery channels in banking scenario (Ong and Cheng, 2003). Some have investigated customer preferences of e-banking (Suganthi et al., 2001; Sohail and Shanmugham, 2003).

This study examines the factors which contributes and enhances the adoption of e-banking in Jordan, and the impact of e-banking functionality on the satisfaction outcomes for Jordanian banks customers. Also, this 
research assesses whether the adoption of e-banking customers in Jordan is constrained by the technology, particularly on the basis of different demographic characteristics, such as different age groups, educational level, income level and etc. Findings of this research are useful for the banking sector in formulating appropriate strategies to build customer satisfaction, loyalty, and positive WOM.

\section{Literature review}

\subsection{Definition of the e-Banking}

The concept of electronic banking has been defined in many ways. Daniel (1999) defines electronic banking as the delivery of banks' information and services by banks to customers via different delivery platforms that can be used with different terminal devices such as a personal computer and a mobile phone with browser or desktop software, telephone or digital television.

Pikkarainen et al (2004) define internet banking as an "internet portal, through which customers can use different kinds of banking services ranging from bill payment to making investments". With the exception of cash withdrawals, internet banking gives customers access to almost any type of banking transaction at the click of a mouse (De Young, 2001). Indeed the use of the internet as a new alternative channel for the distribution of financial services has become a competitive necessity instead of just a way to achieve competitive advantage with the advent of globalization and fiercer competition (Flavián et al, 2004; Gan and Clemes, 2006). Banks use online banking as it is one of the cheapest delivery channels for banking products (Pikkarainen et al, 2004). Such service also saves the time and money of the bank with an added benefit of minimizing the likelihood of committing errors by bank tellers (Jayawardhena and Foley, 2000). Robinson (2000) believes that the supply of internet banking services enables banks to establish and extend their relationship with the customers. There are other numerous advantages to banks offered by online banking such as mass customization to suit the likes of each user, innovation of new products and services, more effective marketing and communication at lower costs (Tuchilla, 2000), development of non-core products such as insurance and stock brokerage as an expansion strategy, improved market image, better and quicker response to market evolution (Jayawardhena and Foley, 2000). Wise and Ali (2009) argued that many banks want to invest in ATMs to reduce branch cost since customers prefer to use them instead of a branch to transact business. The financial impact of ATMs is a marginal increase in fee income substantially offset by the cost of significant increases in the number of customer transactions. The value proposition however, is a significant increase in the intangible item "customer satisfaction". The increase translates into improved customer loyalty that in result in higher customer retention and growing organization value. Internet banking is a lower-cost delivery channel and a way to increase sales. Internet banking services has become one of the most important factors in the business economy today.

\subsection{Factors of Adopting e-Banking}

\subsubsection{Accessibility}

Accessibility defines as the ability of users to access information and services from the web is dependent on many factors. These include the content format; the user's hardware, software and settings; internet connections; the environmental conditions and the user's abilities and disabilities (Godwin-Jones 2001; Hackett and Parmanto, 2009). The term "web accessibility" generally relates to the implementation of website content in such a way as to maximize the ability of users with disabilities to access it. For example, providing a text equivalent for image content of a web page, allows users with some visual disabilities access to the information via a screen reader. The techniques and approaches that create more accessible web pages for people with disabilities also address many other access issues such as download speed and discoverability (Godwin-Jones 2001; Hackett et al, 2004; Hackett and Parmanto, 2009).

Jun et al (1999) revealed reliable/prompt responses, attentiveness, and ease of use had considerable impacts on both customers perceived overall service quality and satisfaction. It also indicated that there is a significant positive relationship between overall service quality and satisfaction. Yang and Jun (2002) redefined the traditional service quality dimensions in the context of online services, and suggested an instrument consisting of seven online service dimensions (reliability, access, ease of use, personalization, security, credibility, and responsiveness).

Joseph et al (1999) considered banking service quality with respect to technology use, such as ATMs, telephone, and the internet and identified six dimensions. They were convenience/accuracy; feedback/complaint management; efficiency; queue management; accessibility; and customization. Therefore, it is hypothesized that accessibility has positive effect on customer satisfaction. 


\subsubsection{Convenience}

E-banking provides higher degree of convenience that enables customers to access internet bank at all times and places. Apart from that, the ease of access of computers is perceived as a measure of relative advantage (Daniel, 1999, Black et al, 2001; Polatoglu and Ekin, 2001; Gerrard and Cunningham, 2003). Johnston (1995) revealed that there are some service quality determinants that are predominantly satisfiers and others that are predominantly dissatisfiers with the main sources of satisfaction being attentiveness, responsiveness, care and friendliness. The main sources of dissatisfaction are integrity, reliability, responsiveness, availability and functionality.

According to Ainscough and Luckett (1996), the provision of customer interactivity is an important criterion that attracts users in the delivery of e-banking. Gerrard and Cunningham (2003) also identify other factors of paramount importance in ensuring the success of e-banking, i.e. the ability of an innovation to meet users' needs using different feature availability on the web site. For instance, the provision of interactive loan calculators, exchange rate converters, and mortgage calculators on the web sites draw the attention of both users and non-users into the bank's web site. A UK study uncovered five key service quality attributes, such as security related issues, convenience, speed and timeliness of the service, and product variety/diverse features (White and Nteli, 2004). Therefore, it is hypothesized that convenience has positive effect on customer satisfaction.

\subsubsection{Privacy}

Customers have doubts about the trust ability of the e-bank's privacy policies (Gerrard and Cunningham, 2003). Trust has striking influence on user's willingness to engage in online exchanges of money and personal sensitive information (Friedman et al, 2000; Wang et al, 2003). Privacy is an important dimension that may affect users' intention to adopt e-based transaction systems. Encryption technology is the most common feature at all bank sites to secure information privacy, supplemented by a combination of different unique identifiers, for instance, a password, mother's maiden name, a memorable date, or a few minutes of inactivity automatically logs users off the account. Besides, the Secure Socket Layer, a widely-used protocol use for online credit card payment, is designed to provide a private and reliable channel between two communicating entities; the use of Java Applet that runs within the user's browser; the use of a Personal Identification Number, as well as an integrated digital signature and digital certificate associated with a smart card system (Hutchinson and Warren, 2003). Thus, a combination of smart card and biometric recognition using fingerprints offers a more secure and easier access control for computers than the password method. Zeithaml et al (2000) developed e-SERVQUAL for measuring e-service quality, identifying 11 dimensions: access; ease of navigation; efficiency; flexibility; reliability; personalization; security/privacy; responsiveness; assurance/trust; site aesthetics; and price knowledge. Hence, it is hypothesized that privacy has a positive effect on customer satisfaction.

\subsubsection{Security}

Assurance about security relates to the extent to which the web site guarantees the safety of customers' financial and personal information, an area which has witnessed a proliferation of research interest (Kimery and McCord, 2002; Miyazaki and Krishnamurthy, 2002). Security can be assured by providing a privacy statement and information about the security of the shopping mechanisms and by displaying the logos of trusted third parties. For example, displaying trusted third party logo guarantees a certain level of security protection and has been shown to significantly influence how consumers regard the trustworthiness of e vendors (Jiang et al, 2008).

Internet banking was made possible by the creation of Web browsers. In this mode of online banking, consumers do not have to purchase additional software (all they need is the browser), store any data on their computer, backup any data, or wait for software upgrades or new versions (Kolsaker and Payne, 2002; Dong-Her et al, 2004). All transactions occur on a secure server of a bank via the internet. The bank has all of the required data and software to execute the transactions. Customers go the bank's Web site, log in, and then take advantage of the bank's internet services. Typical bank services are account access and review, transfers of funds between accounts, bill payment, and then a widening variety of new services and products. Security plays an important role in internet banking and so there are several protocols for internet security of encrypted data packets (Kolsaker and Payne, 2002; Dong-Her et al; 2004). Customers are not aware of the encryption, however, only certain versions of popular internet browsers are acceptable to some banks due to their security limitations (Kolsaker and Payne, 2002; Dong-Her et al; 2004). Therefore, it is hypothesized that privacy has a positive effect on customer satisfaction. 


\subsubsection{Design}

The goal of aesthetic design is to make a web site visually attractive and enjoyable. Proctor et al $(2002,2003)$ discussed content preparation in a broad sense and identified its four aspects: knowledge elicitation, information organization and structure, information retrieval, and information presentation.

During design, and prior to implementation, it is strongly recommended that users of different ages, and with a range of capabilities and limitations be engaged to trial the new service and provide feedback. Financial institutions should test accessibility of their customer websites with both automated tools and user accessibility trials. Therefore, it is hypothesized that design has a positive effect on customer satisfaction.

\subsubsection{Content}

Jayawardhena and Foley (2000) and Pikkarainen et al (2004) claim that content on online banking on the web site is one of the factors influencing online-banking acceptance. On the other hand, quality designs, graphics or colors and the propensity to portray good image of the bank would enhance efficient use of navigation.

In the context of internet banking, there is a growing body of research that has looked at influences on customer satisfaction. Jayawardhena and Foley (2000) illustrated that such web site features as speed, web site content and design, navigation, interactivity and security all influence user satisfaction whereas Broderick and Vachirapornpuk (2002) found that the level and nature of customer participation had the greatest impact on the quality of the service experience and issues such as customers' zone of tolerance, the degree of role understanding by customers and emotional response potentially determined, expected and perceived service quality.

Yang and Fang (2004) found that ease of use and usefulness are important factors in evaluating online service quality. Earlier Doll and Torkzadeh (1988) identified five quality dimensions that have an impact on "end-user" satisfaction in an online environment: content, accuracy, format, ease of use, timeliness. Thus, it is hypothesized that content has positive effect on customer satisfaction.

\subsubsection{Speed}

Hoffman and Novak (1996) find that there is a significant correlation between download speed and user satisfaction. Speed of download depends on the nature of the site downloaded content, the computing hardware and method of connection used to download information (Jayawardhena and Foley, 2000). Most sites demonstration is small snapshots, and some users have to download the program in order to view the demonstration. Most people perceive downloading may import unwanted viruses, and consume hard disk space. Very often, slow response time after any e-interaction leads to a delay of service delivery and makes consumers unsure about whether or not the transaction is completed (Jun and Cai, 2001). Johnston (1997) illustrates that certain actions, such as increasing the speed of processing information and customers, are likely to have an important effect in terms of pleasing customers; however other activities, such as improving the reliability of equipment, will lessen dissatisfaction rather than delight customers and suggests that it is more important to ensure that the dissatisfiers are dealt with before the satisfiers. Thus, it is hypothesized that speed has positive effect on customer satisfaction.

\subsubsection{Fees and Charges}

Service quality attributes in e-banking industry are important since human-internet interaction is the main service delivery and communication channel. Offering high quality services to satisfy consumers' needs, at lower costs, are potential competitive advantage of e-banking. Some studies show that e-banking has successfully reduced operating and administrative costs (Devlin, 1995; Siriluck and Speece, 2003). Cost savings have helped e-based banks offer lower or no service fees, and offer higher interest rates on interest-bearing accounts than traditional banks (Gerlach, 2000; Jun and Cai, 2001). Therefore, it is hypothesized that fees and charges have positive impact on customer satisfaction.

\subsection{Customer Satisfaction and Outcomes of Satisfaction}

In this section the research spotlights on the relevant literature on the concept of satisfaction, its consequences (loyalty and WOM).

\subsubsection{Satisfaction}

Satisfaction has been considered as one of the most important theoretical as well as practical issues for most marketers and customer researchers (Jamal, 2004). Oliver (1981, p. 29) firstly defined it in the consumption context as "the summary psychological state resulting when the emotion surrounding disconfirmed expectations is coupled with the customer's prior feelings about the consumption experience". In other words, we may say 
that satisfaction reflects a post-purchase evaluation of product quality given pre-purchase expectations (Kotler, 1991).

On one hand, within literature on services marketing, satisfaction has traditionally been defined as a cognitive-based phenomenon (Westbrook, 1987). Cognition has been studied mainly in terms of the expectations/disconfirmation paradigm; also known as the confirmation/disconfirmation paradigm, which states that expectations originate from the customer's beliefs about the level of performance that a product/service would provide (Oliver, 1980). Many marketing scholars (Tse and Wilton, 1988 Anderson and Sullivan, 1993; Patterson et al, 1997), indicate that customer satisfaction is related to the size and direction of disconfirmation, which is defined as the difference between the post-purchase and post-usage evaluation of the performance of the product/service and the expectations held prior to the purchase (Sharma and Ojha, 2004).

On the other hand, other studies (Dube-Rioux, 1990; Homburg et al, 2006) have recognized that the affect experienced during the acquisition and consumption of the product or service can also have a significant influence on satisfaction judgments (Homburg et al, 2006). Dube-Rioux (1990) points out that a consumer affective response can be used to predict satisfaction more accurately than cognitive evaluation. Therefore, it is hypothesized that customer satisfaction has positive impact on customer loyalty.

\subsubsection{Loyalty}

Oliver (1999, p. 34) defines loyalty as "a deeply held commitment to re-buy or repatronize a preferred product/service consistently in the future, thereby causing repetitive same brand or same brand-set purchasing, despite situational influences and marketing efforts having the potential to cause switching behavior". Broadly, loyalty development has been an objective traditionally aimed at by managers (Andreassen, 1999) since it enables higher future purchase intention. In particular, loyalty may be defined as a customer's intention or predisposition to purchase from the same organization again (Edvardsson et al, 2000), that result from the conviction that the value received from one seller is greater than the value available from other alternatives (Hallowell, 1996). As a consequence, loyalty has been considered to be a key factor in order to achieve company success and sustainability over time (Flavián et al, 2006; Keating et al, 2003), and several authors have proposed that loyalty also favors higher intensity in positive WOM (Hallowell, 1996), lower price sensibility (Lynch and Ariely, 2000) and more stable and bigger incomes (Knox and Denison, 2000). Therefore, it is hypothesized that loyalty has positive impact on WOM.

\subsubsection{WOM}

Word-of-mouth (WOM) is an informal mode of communication between private parties concerning the evaluation of goods and services (Singh, 1988). Marketing literature has consistently shown its powerful role in influencing consumers' attitudes. For example, WOM is found to have more influence on product judgments than less vivid printed information (Herr et al, 1991).

In general, WOM may be defined as an informal type of communication between private parties concerning the evaluation of goods and services and it has been considered to be one of the most powerful forces in the market place (Bansal and Voyer, 2000).

To be precise, the importance of WOM resides in the fact that consumer choice is usually influenced by WOM, especially when the purchase in important. This is explained due to the fact that consumers prefer to rely on informal and personal communication sources in making purchase decisions instead of on formal and organizational sources such as advertising campaigns (Bansal and Voyer, 2000).

The specific references only partially covered the e-banking and outcomes of satisfaction. Therefore, the present research attempts to fill a gap in the subject of e-banking in Jordanian commercial banks. The study addressed some of the shortcomings in the literature such as looking at the e-banking functionality factors from the point of view of accessibility, convenience, security, privacy, content, design, speed, fees and charges, to investigating the influences of e-banking on outcomes of satisfaction in the Jordanian commercial banks. It was established that no previous research had been conducted at Jordanian commercial banks, which investigated the relationship between the e-banking and the outcomes of satisfaction namely loyalty and positive WOM in the Jordanian commercial banks.

\section{Research Objectives}

Based on the research questions and relevant literature of the e-banking, customer satisfaction, loyalty and WOM, the research objectives are:

1). To reveal the adoption of e-banking factors in the Jordanian commercial banks. 
2). To determine the factors which constitute e-banking functionality in the Jordanian commercial banks?

3). To examine the effect of e-banking on customer satisfaction.

4). To examine the effect of customer satisfaction on outcomes of satisfaction namely (loyalty and WOM).

\section{Research Methodology}

\subsection{Population and Sample}

Our research population is all the banks that are operating in Jordan and are registered with the Central Bank of Jordan. There are 24 commercial banks operating in Jordan (Central Bank of Jordan, 2009).

The research population consisted of all the customers who have an account at any commercial banks in the Hashemite Kingdom of Jordan. Therefore, all the banks customers were called and invited to participate in the research survey. Since all their headquarters are located in Amman, the whole population was invited to participate in the survey. The researchers gathered 185 questionnaires, yielding a response rate of 74 per cent. Finally, 179 (71.6 per cent) questionnaires were fully and correctly completed. All data collection procedures were designed to ensure the anonymity. Respondents typically held purposive sample.

It should be noted that every questionnaire was personally handed and instructions were given to each customers before completing the questionnaire. In terms of demographic findings, $(70.4 \%)$ of respondents were males, and the remaining $(29.6 \%)$ were females. In terms of the age group of respondents, it is interested to note that (27.4\%) of them are less than (26) years, whereas (29.1\%) fell into the (26-30) age group, whereas (15.1\%) fell into the (31-35) age group, whereas (12.3\%) fell into the (36-40) age group, whereas $(8.4 \%)$ fell into the (41-45) age group, only (7.8\%) are above this group. As for the educational levels of those customers, the majority (60.9\%) were university degree holders, and some those $(10.1 \%)$ of these, have postgraduate degree. As for the computer literacy of those customers, were all of them $(100 \%)$ were computer literacy, As for the internet accessibility at home/office of these customers, the majority (89.9\%) were internet accessibility at home/office. See table (1).

\subsection{Data Collection}

The research questionnaire was designed based on previous empirical literature. The questionnaire design was pre-tested and redesigned through personal interviews with bank managers and banks customers by undertaking the pilot study work (Aaker et al, 2001).

The research questionnaire was used as primary data collection method as shown in (Table 2, 3, 4). The components of e-banking and outcomes of customer satisfaction items were measured on 5-point Likert- scale ranging from 5 (strongly agree) to 1 (strongly disagree). For the e-banking and outcomes of customer satisfaction dimensions, the research respondents were asked to indicate the degree of agreement or disagreement on the ebanking items that banks used e-banking technique in order to achieve customer satisfaction. For the outcomes of satisfaction, the respondents were asked to indicate how important they believed of customer satisfaction. Multiple items were used to assess their measurement properties. Consistent with the literature, the scale items selected for the dependent variable were direct measures of customer satisfaction with influences received from adoption of e-banking functionality as independent variables. This format has been recommended for marketing and banking surveys.

Both the independent and dependent variable(s) deployed in the research are explained in Table 2, 3and 4 according to the proposed hypotheses.

Table 2: adoption of e-banking factors: Independent variables

Accessibility (independent variable)

Hypothesis 1: accessibility has a positive significant influence on customer satisfaction.

Accessibility in the Jordanian commercial banks was measured on:

Internet accessibility, site has details when the bank charges apply, site has details of overdraft facilities, site has details on how to fund transfer between accounts, site has details on competitors' interest rates, exchange rate and foreign exchange, details on security arrangements, site has a search engine.

Convenience (independent variable)

Hypothesis 2: Convenience has a positive significant influence on customer satisfaction.

The measure for this factor consists of: access anytime and anywhere, no queue, save time as compared to conventional banking, e-banks transaction is easy to use, user friendly, easy login, check transaction details and statement regularly, computer literate keeps me using e-banking services. 
Security (independent variable)

Hypothesis 3: security accessibility has a positive significant influence on customer satisfaction.

The authorized username and password are important, saving login number and password on the computer, leaving computer unattended, while connected to the e-banking services, Trust affects the demand for e-banking services, Pins obtain by fraud may allow hackers to access to customers' account, don't mind registering before supplying information, Banks' reliability in correcting erroneous transactions, Trust the bank will compensate for losses due to security reasons, satisfying with the security system.

Privacy (independent variable)

Hypothesis 4: privacy has a positive significant influence on customer satisfaction.

Privacy influences consisted of evaluating: Confidential information is delivered safely from banks to customers, Customers' financial information may be passed on to other companies among the banks, third parties are able to assess customers' financial details, Banking institutions keep customers information private and confidential, trust the bank's privacy protection to the users, Continuous improvement on online systems.

Content (independent variable)

Hypothesis 5: Content has a positive significant influence on customer satisfaction

content influences consisted of evaluating: clear and easy guidance screen, clear and simple help menus allow me to perform e-banking transaction easily, Information credibility, willing to seek helps from the customer services when I encounter problems, E-banking services have been upgraded compared to, I first started using the services.

Design (independent variable)

Hypothesis 6: design has a positive significant influence on customer satisfaction

The role of design was assessed by measuring: Attractiveness screen layout and design, Site has flashy graphics and color configuration, Web site design is important.

Speed (independent variable)

Hypothesis 7: speed has a positive significant influence on customer satisfaction

This factor measured by: Frequent connection breakdown, Easy to navigate the bank site due to smooth speed, Transition is efficient/no waiting time, Response speed to complaint is satisfactory, Speed of e-transactions flow is faster than traditional banking channels.

Fees and charges (independent variable)

Hypothesis 8: fees and charges have a positive significant influence on customer satisfaction

The role of fees and charges were assessed by measuring: Prices of computer are reasonable and affordable, Fee of internet connection is affordable, E-banks charge lower transaction fees, Continue using although need to pay low subscription fees, I won't terminate services even if bank charges annual fee, E-banks charge annual fee, Time saving using e-banking services, Price of service fees is acceptable.

Table 3: Customer Satisfaction: dependent variable/ independent variable (mediation).

Customer satisfaction (dependent variable)

Hypothesis 9: customer satisfaction has a positive significant influence on customer loyalty

The measurement of performance was assessed by: customer made the correct decision to use this website, the experience that had with this website has been satisfactory, and customer satisfied with the way that this website has carried out transactions, and customer satisfied with the service have received from the website.

Hypothesis 10: customer loyalty has a positive significant influence on WOM.

Table 4: customer loyalty: dependent variable/ independent variable

Customer loyalty: I have the intention to continue my relationship with this website, Based on my experience, I am very likely continuing my relationship with this website in the next months.

WOM (dependent variable): Will recommend this website to other customers, I will point out the positive aspects of this website if anybody criticizes it.

Hypothesis 11: customer satisfaction has a positive significant influence on WOM 


\section{Results and Discussion}

Our basic assumptions are that e-banking functionality factors namely (accessibility, convenience, security, privacy, content, design, speed, fees and charges) influence satisfaction and outcomes of satisfaction namely loyalty and positive word of mouth. A multiple regression modeling approach was proposed as an effective method for studying the relationships. As displayed in Table 5, the adjusted R2 is 0.446 , suggesting that the eight e-banking factors explain close to 45 per cent of the variance for the dimension of satisfaction. Specifically, other Tables also act variables have a statistically significant effect on satisfaction.

Of these significant variables, security, privacy, and content appear to have the greatest impact on satisfaction.

In addition, it predicted that the influence of such factors (accessibility, convenience, security, privacy, content, design, speed, fees and charges) on satisfaction would differ according to the personal variables, which are personal characteristics and their experience in computers (as shown in table 5). The results of the multiple regression analysis signal that there is variation in the effect of e-banking functionality factors on satisfaction and empirical evidence in this research suggests that e-banking factors have a significant degree of influence on satisfaction and outcomes of satisfaction. This empirical evidence has provided significant support for the e-banking literature, which substantively advocates that e-banking functionality factors have an impact on outcome of satisfaction.

The results empirically substantiate that e-banking functionality factors play a fundamental role in the satisfaction among Jordanian commercial banks.

\subsection{The e-banking functionality factors has a positive significant influence on customer satisfaction}

Empirically, the model assumed that e-banking functionality factors positively influence customer satisfaction in the Jordanian commercial banks. In addition, it predicted that the influence of such factors on customer satisfaction would differ according to the personal variable that is gender, age, marital status, educational level, computer literacy, and internet accessibility (table 5). The results of the multiple regression analysis signal that there is variation in the effect of e-banking factors on customer satisfaction and empirical evidence in this research suggests that adoption of e- banking factors have a significant degree of influence on customer satisfaction. This empirical evidence has provided significant support for the electronic banking literature, which substantively advocates that e-banking factors have an influence on customer satisfaction (Jayawardhena and Foley, 2000; Robinson, 2000; Pikkarainen et al, 2004; Gan et al, 2006; Hua, 2009; Wise and Ali, 2009).

The results empirically substantiate that using of e-banking services play a fundamental role in the customer satisfaction among Jordanian commercial banks.

\subsection{Accessibility has a positive significant influence on customer satisfaction}

The findings in table (6) provide significant support for the accessibility literature which advocates that accessibility have an influence upon Jordanian commercial banks. As a consequence, we are able to substantiate that accessibility has a significant influence on customer satisfaction. These findings are also consistent with other research findings (for example, Godwin-Jones 2001; Hackett and Parmanto, 2009)

\subsection{Convenience has a positive significant influence on customer satisfaction}

Convenience is also considered to be one of the influential factors on the satisfaction of Jordanian commercial banks (table 7). Prior research has empirically found positive relationship between convenience and satisfaction as critical factors on the use of e-banking (Venkatesh and Davis, 1996; Johnson and Marakas, 2000; Hong et al, 2001; Chau, 2001; Wang et al, 2003; Pikkarainen et al, 2004).

These results are not surprising as when Jordanian commercial banks consider the convenience as a competitive tool; this might impact positively on the adapting and generalize the using of e-banking in Jordan. As a result, we are able to confirm that convenience have a significant influence on customer satisfaction. These findings are also consistent with other research findings. For example, (Devlin, 1995; Daniel, 1999, Black et al, 2001; Polatoglu and Ekin, 2001; Suganthi et al, 2001; Gerrard and Cunningham, 2003) found that e-banking provides higher degree of convenience that enables customers to access internet bank at all times and places.

\subsection{Privacy has a positive significant influence on customer satisfaction}

Examining data appears that a pre-requisite for survival and growth is that both the banks and its customers have an interest in their joint relationship - leading to a win-win effect. Factors such as confidential information is delivered safely from banks to customers; trust the bank's privacy protection to the users should help to build effective relationships and increase the customer satisfaction in the long run. 
Banks customers have doubts about the trust ability of the e-bank's privacy policies (Gerrard and Cunningham, 2003). Trust has striking influence on user's willingness to engage in online exchanges of money and personal sensitive information (Hoffman et al, 1999; Friedman et al, 2000; Wang et al, 2003). Privacy is important dimension that may affect users' intention to adopt e-based transaction systems.

Privacy consider as one of the most influential factor on customer satisfaction as shown in table (8).

\subsection{Security has a positive significant influence on customer satisfaction}

An examination of table (9) suggests that security is an influential factor on customer satisfaction in Jordanian commercial banks. The results therefore, substantiate that security has a positive bearing on customer satisfaction. These findings are also consistent with other research findings. For example, (Daniel, 1999, Black et al, 2001; Polatoglu and Ekin, 2001; Suganthi et al, 2001; Gerrard and Cunningham, 2003) found that e-banking provides higher degree of security that enables customers to trust internet banking at all times and places.

\subsection{Design has a positive significant influence on customer satisfaction}

Design is also considered to be one of the influential factors on the satisfaction of Jordanian commercial banks customers (table 10). Prior research has empirically found positive relationship between banks web design and customer satisfaction as critical factors on the use of e-banking (Fang and Salvendy, 2003; Lazar and Sears, 2006).

These results indicate that the web design is an important element to facilitate the using of e-banking which is reflects on the customer satisfaction. Other researches have empirically found positive relationship between bank web site design and customer satisfaction as critical factors on the use of e-banking (Fang and Salvendy, 2003; Lazar and Sears, 2006; Vu and Proctor, 2006).

\subsection{Content has a positive significant influence on customer satisfaction}

Examining data in table (11), it appears that content of bank site has a positive significant influence on the acceptance of adopting this service by Jordanian commercial banks customers. Factors such as information credibility; Clear and simple help menus allow customers to perform e-banking transaction easily should help users to build effective relationships and increase the customer satisfaction in the long run.

Content is important dimension that may affect users' intention to adopt e-banking systems. Other researches have empirically found positive relationship between bank web content and customer satisfaction as critical factors on the use of e-banking (Friedman et al, 2000; Hutchinson and Warren, 2003; Wang et al, 2003).

\subsection{Speed has a positive significant influence on customer satisfaction}

Our findings in table (12) provide support for speed having a statistically significant positive effect on customer satisfaction. This finding is similar to the work of Hoffman and Novak (1996) that identified speed as a major factor influencing customer satisfaction. Other researches have empirically found positive relationship between e-banking speed and customer satisfaction as critical factors on the use of this service (Hoffman and Novak, 1996; Jayawardhena and Foley, 2000).

\subsection{Fees have a positive significant influence on customer satisfaction}

Fees are also considered to be one of the influential factors on the customer satisfaction of Jordanian commercial banks customers (table 13). Prior research has empirically found positive relationship between e-banking fees and customer satisfaction as critical factors on the use of e banking (Devlin, 1995; Gerlach, 2000; Jun and Cai, 2001; Siriluck and Speece, 2003).

These results indicate that the fees determine by Jordanian banks are an important element to facilitate the using of e-banking which is reflects on the customer satisfaction. Other researches have empirically found positive relationship between fees rate and customer satisfaction as critical factors on the use of e- banking (Devlin, 1995; Gerlach, 2000; Jun and Cai, 2001; Siriluck and Speece, 2003).

In summary, it can be seen that all e-banking functionality factors, which accessibility, convenience, security, privacy, content, design, speed, fees and charges, have proven to positively customer satisfaction.

Examining data in tables $(14,15,16)$ it appear that customer satisfaction has a positive significant influence on customer loyalty of adopting e-banking service by Jordanian commercial banks. This result generalized on the other research outcomes (loyalty on positive WOM and also customer satisfaction on positive WOM).

Loyalty and WOM were explained at a similar level in the proposed model (R2 loyalty $=0.375$, R2 SAT influence $\mathrm{WOM}=0.362$ ). Generally speaking, we can conclude that satisfaction is a key mediating factor in the loyalty and positive WOM in the e-banking services in Jordanian commercial banks. 


\section{Implications}

The theoretical underpinning of this research is based on literature from the e-banking relating to commercial banks within the banking industry. Service marketing scholars have long since recognized the crucial characteristics of service intangibility, inseparability, heterogeneity, fiduciary, and perishability, lack of transfer of title (Zeithaml et al, 1985; Harrison, 2000). The recognition of such characteristics has led researchers to recognize the key role played by service marketers in improving service delivery and accessibility to shed light on the important role of marketing within service sectors, especially in the provision of banking services. The empirical conclusions drawn from this research are multifaceted and as a result, it is vitally important that banks managers pay attention to the influences of customer satisfaction. Researchers are therefore encouraged to place more focus on the impact influences stemming from the e-banking functionality and its impact on customer satisfaction within Jordanian commercial banks.

In addition, adoption of e-banking has not been previously identified as crucial inputs for satisfaction by banks managers operating within the commercial banks sector.

\section{Conclusion}

This research seeks to make an original contribution to knowledge by investigating the impact of e-banking factors on outcomes of customer satisfaction in the commercial banks industry in Jordan. This research contributes to the services marketing discipline in finding out the role of the e-banking in enhancing customer satisfaction and loyalty.

Factors pertaining to accessibility, convenience, security, privacy, content, design, speed, fees and charges were a focus of this study as they have an influence on customer satisfaction.

Contributions found will be beneficial for both academics and managers alike. Academically, this work aims to focus academic attention upon a much neglected domain - the marketing and information technology of banking services in Jordan. There is currently a distinct lack of studies in academia relating to research in the Middle East. This is somewhat surprising when considering that Jordan has been at the forefront of the banking services industry in the Middle East.

In fact, the banking services industry is an important and vibrant sector in Jordan and banks are considered as an important segment of the financial services provider where customers can receive a wide range of financial services.

Although this research has provided valuable insights into a somewhat scant area of research, it has been subject to some limitations. To begin with, there were some difficulties in the distribution of the research questionnaire within the customers of Jordanian commercial banks, possibly leading to some inconsistencies in the data collection process. For example, a portion of banks opted to distribute the instrument to respondents themselves, where in other cases the researcher delivered the survey to respondents individually. In addition, this research has been conducted within a single service industry and exclusively in the Jordanian commercial banks sector, thus limiting the generalisability of the research results to the foreign banks and other financial organizations in Jordan.

Future research is therefore required to extend these results in other geographical areas and among managerial employees at these banks. For example, the concept could be extended to other Arab countries in order to validate the model and findings. By studying other service and financial services (for example, specialty banks, money transfer services, insurance companies) a model could be developed to better represent the service sector in more general, rather than focusing on the commercial banks alone. The inclusion of employees at all service levels would allow for more insight to be gathered on employees' viewpoints, attitudes, perceptions and overall satisfaction of outcomes of satisfaction.

Future research should also investigate whether the model could be used for a comparative study between the service sector and the industrial sector, testing for the differences and effects of electronic functionality factors in both sectors. By doing so, it would be interesting to test whether the model could hold across a range of industries and service sectors apart from banking industry.

\section{References}

Aaker, D., V. Kumar, and G. Day. (2003). Marketing research. 800 p. 7th ed., John Wiley and Sons, New York, USA.

Ainscough, T.L., \& Luckett, M.G. (1996).The internet for the rest of us: marketing on the World Wide Web. Journal of Consumer Marketing, 13 (2), 36-47 
Allen, F., McAndrews, J., \& Strahan, P. (2001). E-finance: An Introduction, Working Paper No. 01-36. Financial Institutions Center, Wharton University, Philadelphia, PA, 7 October,

Anderson, E.W., \& Sullivan, M.W. (1993). The antecedents and consequences of customer satisfaction for firms. Marketing Science, 12, (2), 125-43.

Andreassen, T.W. (1999). What drives customer loyalty with complaint resolution?. Journal of Service Research, $1,(4), 324-32$

Bansal, H., \& Voyer, P. (2000). Word-of-Mouth Processes Within a Service Purchase Decision Context. Journal of Service Research, 3, (2), 166-77.

Black, N.J., Lockett, A., Winklhofer, H., \& Ennew, C. (2001). The adoption of Internet financial services: A qualitative study. International Journal of Retail \&Distribution Management, 29(8), 390-398.

Broerick, A Vachirapornpuk, S. (2002). Service quality in Internet banking: the importance of customer role. Marketing Intelligence \& Planning, 20, (6), 327 - 335.

Central Bank of Jordan. (2009). Annual Report, HKJ.

Daniel, E. (1999). Provision of electronic banking in the UK and the Republic of Ireland. International Journal of Bank Marketing, 17(2), 72-82.

Devlin, J.F. (1995). Technology and innovation in retail banking distribution. International Journal of Bank Marketing, 13, (4), 19-25.

DeYoung, R. (2001). The financial performance of pure play Internet banks. Economic Perspectives, 25, (1), 60-75.

Doll, W.J., \& Torkzadeh, G. (1988). The measurement of end-user computing satisfaction. MIS Quarterly, 12, (2), 259-74.

Dong-Her, S., Hsiu-Sen, C., Chun-Yuan, C., Lin, B. (2004). Internet security: malicious e-mails detection and protection. Industrial Management \& Data Systems, 104,(7), 613-23.

Dube-Rioux, L. (1990). Power of affective reports in predicting satisfaction judgments. in Goldberg, M., Gorn, G.,Pollay, R. (Eds). Advances in Consumer Research,17, 571-6.

Edvardsson, B., Johnson, M.D., Gustafsson, A., \& Strandvik, T. (2000). The effects of satisfaction and loyalty on profits and growth: products versus services. Total Quality Management, 11, 917-27.

Flavián, C., Guinalíu, M., \& Gurrea, R. (2006). The role played by perceived usability, satisfaction and consumer trust on website loyalty. The International Journal of Information Systems Applications, 43, (1), 1-14.

Flavian, C., Torres, E., and Guinaliu, M. (2004). Corporate image measurement: a further problem for the tangibilization of internet banking services. International Journal of Bank Marketing, 22 (5), 366-84.

Friedman, B., Kahn, P.H. Jr, \& Howe, D.C. (2000). Trust online. Communications of the ACM, 43, (2),34-40.

Gan, C and Clemes, M. (2006). A logit analysis of electronic banking in New Zealand. International Journal of Bank Marketing, 24 (6), 360-383.

General Statistic Bureau. (2009). Annual Report, HKJ.

Gerlach, D. (2000). Put your money where your mouse is. PC World, .March, 191-9.

Gerrard, P., \& Cunningham, J. (2003). The diffusion of internet banking among Singapore consumers. International Journal of Bank Marketing, 21, (1), 16-28.

Goodwin-Jones, B. (2001). Emerging technologies - accessibility and web design why does it matter? Language Learning and Technology, 5, 11-19.

Hackett, S., Parmanto, B., \& Zeng, X. (2004). ASSETS'04. ACM, Atlanta, GA, .18-20 October, 32-9.

Hackett, S., B. Parmanto and X. Zeng. (2004). Accessibility of Internet Websites through Time. Association for Computing Machenary, Atlanta, USA.

Hackett, S \& Parmanto, B. (2009). Homepage not enough when evaluating web site accessibility. Internet Research, 19, (1),78-87.

Hallowell, R. (1996). The relationships of customer satisfaction, customer loyalty, and profitability: an empirical study. International Journal of Service Industry Management, 7, (4), 27-42.

Harrison, T. (2000). Financial services marketing. Prentice Hall. 
Herr, P., Kardes, F., and Kim, J. (1991). Effects of Word-of-Mouth and Product Attribute Information on Persuasion: an Accessibility-Diagnocisticity Perspective. Journal of Consumer Research, 17, 454-462.

Hoffman, D.L., Novak, T.P., \& Peralta, M. (1999). Building consumer trust online. Communications of the ACM, $42,(4), 80-5$.

Homburg, C., Koschate, N., \& Hoyer, W.D. (2006). The role of cognition and affect in the formation of customer satisfaction: a dynamic perspective. Journal of Marketing, 70, July, 21-31.

Hutchinson, D., \& Warren, M. (2003). Security for internet banking: a framework. Logistic Information Management, 16, (1), 64-73.

Jamal, A. (2004). Retail banking and customer behaviour: a study of self concept, satisfaction and technology usage. The International Review of Retail, Distribution and Consumer Research, 14, (3), 357-379.

Jayawardhena, C., \& Foley, P. (2000). Changes in the banking sector - the case of Internet banking in the UK. Internet Research: Electronic Networking Applications and Policy, 10, (1), 19-30.

Jiang, Pingjun, David B. Jones, and Sharon Javie. (2008). How Third-Party Certification Programs Relate to Consumer Trust in Online Transactions: An Exploratory Study. Psychology \& Marketing, 25 (9), 839-858.

Johnston, R. (1995). The determinants of service quality: satisfiers and dissatisfies. International Journal of Service Industry Management, 6, (5), 53-71.

Joseph M, McClure C \& Joseph B. (1999). Service quality in the banking sector: the impact of technology on service delivery. International Journal of Bank Marketing, 17(4), 182-191.

Jun, M., \& Cai, S. (2001). The key determinants of internet banking service quality: a content analysis. International Journal of Bank Marketing, 19, (7), 276-91.

Jun, M., Peterson, R., Zsidisin, G., \& Daily, B. (1999). Service quality perceptions in the banking industry: major dimensions. Journal of Business Strategies, 16, (2), 170-88.

Keating, B., Rugimbana, R., \& Quazi, A. (2003). Differentiating between service quality and relationship quality in cyberspace. Managing Service Quality, 13, (3), 217-32.

Kimery, K.M., \& McCord, M. (2002). Third-party assurances: mapping the road to trust in e-retailing. Journal of Information Technology Theory and Applications, 4, (2), 63-82.

Knox, S.D., \& Denison, T.J. (2000). Store loyalty: its impact on retail revenue. An empirical study of purchasing behaviour in the UK. Journal of Retailing and Consumer Services, 7, (1), 33-45.

Kolsaker, A Payne, C. (2002). Engendering trust in e-commerce: a study of gender-based concerns. Marketing Intelligence \& Planning, 20 (4), $206-214$.

Lynch, J.G., \& Ariely, D. (2000). Wine online: search costs affect competition on price quality and distribution. Marketing Science, 19, (1), 83-103.

Miyazaki, A.D., \& Krishnamurthy, S. (2002). Internet seals of approval: effects on online privacy policies and consumer perceptions. The Journal of Consumer Affairs, 36, (1), 28-49.

Oliver, R.L. (1999). Whence consumer loyalty?. Journal of Marketing, 63, 33-44.

Oliver, Richard L. (1980). A Cognitive Model of the Antecedents and Consequences of Satisfaction Decisions. Journal of Marketing Research, 17, (September), 460-469.

Oliver, Richard, L. (1981). Measurement and Evaluation of Satisfaction Process in Retail Setting. Journal of Retailing, 57, (Fall), 25-48.

Ong, H.B., \& Cheng, M.Y. (2003). Success factor in e-channels: the Malaysian banking scenario. International Journal of Bank Marketing, 21, (6), 369-77.

Park, C., \& Jun, J.K. (2003). Effects of internet usage, perceived risks, and innovativeness. International Marketing Review, 20, (5), 534-53.

Patterson, P.G., Johnson, L.W., \& Spreng, R.A. (1997).Modeling the determinants of customer satisfaction for business-to-business professional services. Journal of the Academy of Marketing Science, 25, (1), 4-17.

Pikkarainen, T., Pikkarainen, K., Karjaluoto, H., and Pahnila, S. (2004). Consumer acceptance of online banking: an extension of the technology acceptance model. Internet Research, 14, (3). 
Polatoglu, V.N., \& Ekin, S. (2001). An empirical investigation of the Turkish consumers' acceptance of Internet banking services. International Journal of Bank Marketing, 19(4), 156-165.

Proctor, R.W., Vu, K., \& Salvendy, G., et al.. (2002). Content Preparation and Management for Web Design: Eliciting, Structuring, Searching, and Displaying Information. International Journal of Human-Computer Interaction, 14, (1), 25-92.

Quelch, J.A., \& Klein, L.R. (1996). The internet and international marketing. Sloan Management Review, spring, 60-75.

Robert W. Proctor, Kim-Phuong L. Vu, Lawrence J. Najjar, Misha W. Vaughan, \& Gavriel Salvendy. (2003). Content preparation and management for e-commerce Web sites. Communications of the ACM, .46, (12), December.

Robinson, T. (2000). Internet banking: still not a perfect marriage. Informationweek.com, April 17, pp.104-106.

Sharma, N., \& Ojha, S. (2004). Measuring service performance in mobile communication. The Service Industries Journal, 24, (6), 109-28.

Singh, J. (1990). Voice, Exit and Negative Word of Mouth Behaviours: An Investigation Across Three Service Categories. Journal of the Academy of Marketing Science, 18, 1-15.

Siriluck, R., \& Speece, M. (2003). Barriers to internet banking adoption: a qualitative study among corporative customers in Thailand. International Journal of Bank Marketing, 21, (6), 312-23.

Sohail,M.S., \& Shanmugham, B.E-b. (2003). E-banking and customer preferences in Malaysia: an empirical investigation. Information Sciences, 150,207-17.

Suganthi, S., Balachandher, K.G., \& Balachandran, S. (2001). Internet banking patronage: an empirical investigation of Malaysia. Journal of Internet Banking and Commerce, [Online] Available: www.arraydev.com/commerce/JIBC/0103_01.htm, 6, (1).

Tse, D.K., \& Wilton, P.C. (1988). Models of customer satisfaction formation: an extension. Journal of Marketing Research, 25, (2), 204-12.

Tuchila, R. (2000). Servicii bancare prin Internet. E-finance Romania, 3, (3), 23.

Wang, Y.S., Wang, Y.M., Lin, H.H., \& Tang, T.I. (2003). Determinants of user acceptance of internet banking: an empirical study. International Journal of Service Industry Management, 14, (5), 501-19.

Westbrook, R.A. (1987). Product/consumption-based affective responses and post-purchase processes. Journal of Marketing Research, 24 , (3), 258-70.

White, H., \& Nteli, F. (2004). Internet banking in the UK: why are there not more customers?. Journal of Financial Services Marketing, 9, 49-57.

Wise, Victoria and Ali, Muhammad Mahboob. (2009). Customer Relationship Management in Banks with special reference to Bangladesh. Southwest Review of International Business Research, 19, (1), March.

Yang, Z., and Fang, X. (2004). Online service quality dimensions and their relationships with satisfaction: A content analysis of customer reviews of securities brokerage services. International Journal of Service Industry Management, 15(3), 302-326.

Yang, Z., \& Jun, M. (2002). Consumer perception of e-service quality: from internet purchaser and non-purchaser perspectives. Journal of Business Strategies, 19 (1), 19-41.

Zeithaml, V.A., Parasuraman, A., \& Malhotra, A. (2000). A conceptual framework for understanding e-service quality: implications for future research and managerial practice. Marketing Science Institute and Dell star, working paper. 
Table 1. Characteristics of the Sample $(\mathrm{N}=179)$

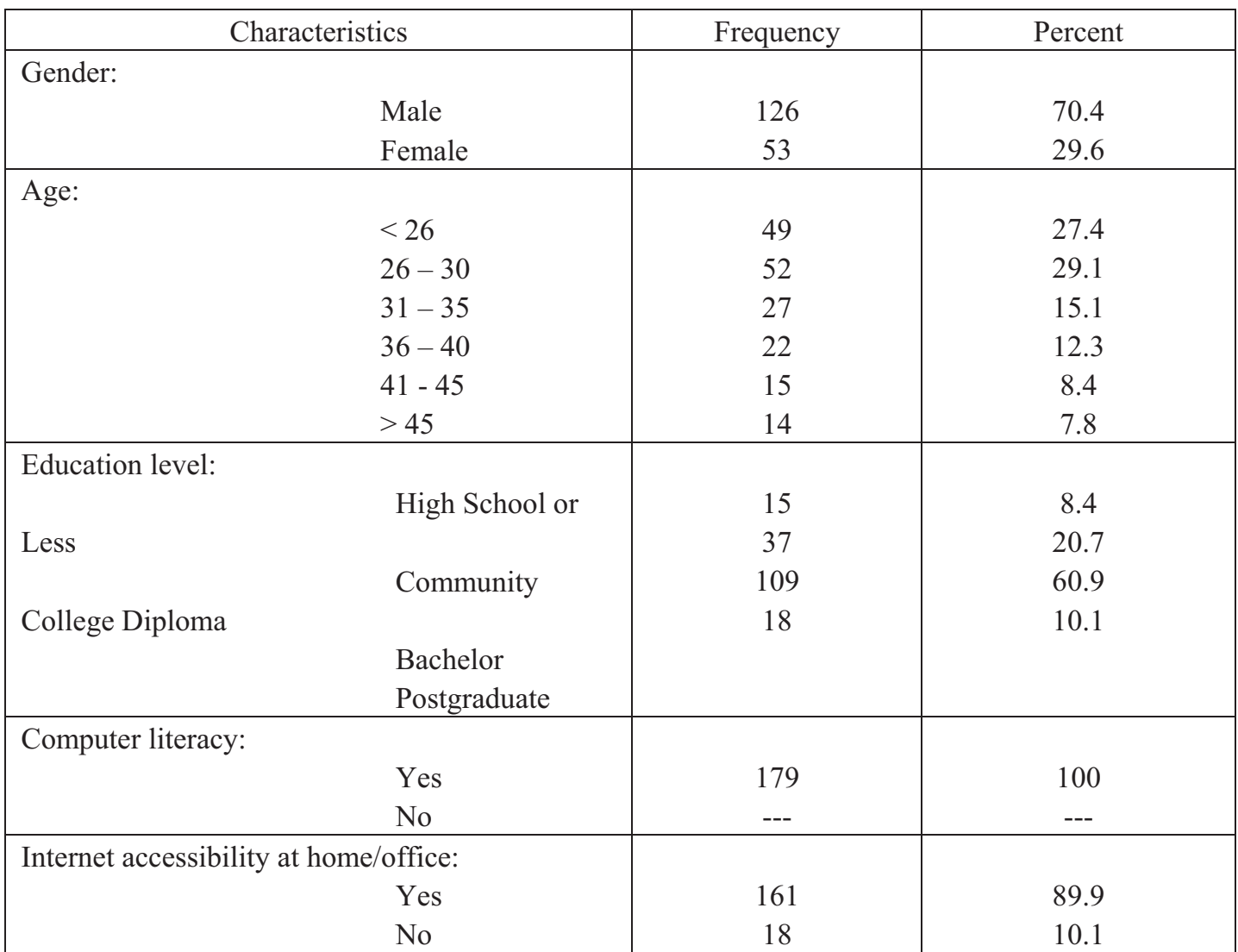

Table 2. Results - adopting of e-banking (customer satisfaction)

\begin{tabular}{|l|c|c|c|c|c|}
\hline $\begin{array}{l}\text { E-banking } \\
\text { factors }\end{array}$ & $\mathrm{B}$ & $\begin{array}{c}\text { Standardized } \\
\text { error }\end{array}$ & Beta & t-value & Significant \\
\hline $\begin{array}{l}\text { E-banking } \\
\text { factors }\end{array}$ & 0.800 & 0.432 & 0.197 & 3.157 & 0.004 \\
\hline
\end{tabular}

Table 3. Results - Accessibility / (customer satisfaction)

\begin{tabular}{|l|c|c|c|c|c|}
\hline $\begin{array}{l}\text { E-banking } \\
\text { factors }\end{array}$ & B & $\begin{array}{c}\text { Standardized } \\
\text { error }\end{array}$ & Beta & t-value & Significant \\
\hline Accessibility & 0.781 & 0.765 & 0.654 & 2.765 & 0.045 \\
\hline
\end{tabular}

Table 4. Results - Convenience / (customer satisfaction)

\begin{tabular}{|l|c|c|c|c|c|}
\hline $\begin{array}{l}\text { E-banking } \\
\text { factors }\end{array}$ & B & $\begin{array}{c}\text { Standardized } \\
\text { error }\end{array}$ & Beta & t-value & Significant \\
\hline Convenience & 0.700 & 0.325 & 0.213 & 2.154 & 0.034 \\
\hline
\end{tabular}

Table 5. Results - Security / (customer satisfaction)

\begin{tabular}{|l|c|c|c|c|c|}
\hline $\begin{array}{l}\text { E-banking } \\
\text { factors }\end{array}$ & B & $\begin{array}{c}\text { Standardized } \\
\text { error }\end{array}$ & Beta & t-value & Significant \\
\hline Security & 1.305 & 0.342 & 0.360 & 3.815 & 0.000 \\
\hline
\end{tabular}


Table 6. Results - Privacy / (customer satisfaction)

\begin{tabular}{|l|c|c|c|c|c|}
\hline $\begin{array}{l}\text { E-banking } \\
\text { factors }\end{array}$ & B & $\begin{array}{c}\text { Standardized } \\
\text { error }\end{array}$ & Beta & t-value & Significant \\
\hline Privacy & 1.210 & 0.354 & 0.312 & 2.752 & 0.000 \\
\hline
\end{tabular}

Table 7. Results - Design / (customer satisfaction)

\begin{tabular}{|l|c|c|c|c|c|}
\hline $\begin{array}{l}\text { E-banking } \\
\text { factors }\end{array}$ & B & $\begin{array}{c}\text { Standardized } \\
\text { error }\end{array}$ & Beta & t-value & Significant \\
\hline Design & 0.144 & 0.543 & 0.333 & 2.659 & 0.047 \\
\hline
\end{tabular}

Table 8. Results - Content / (customer satisfaction)

\begin{tabular}{|l|c|c|c|c|c|}
\hline $\begin{array}{l}\text { E-banking } \\
\text { factors }\end{array}$ & B & $\begin{array}{c}\text { Standardized } \\
\text { error }\end{array}$ & Beta & t-value & Significant \\
\hline Content & 2.640 & 0.440 & 0.519 & 6.006 & 0.000 \\
\hline
\end{tabular}

Table 9. Results - Speed / (customer satisfaction)

\begin{tabular}{|l|c|c|c|c|c|}
\hline $\begin{array}{l}\text { E-banking } \\
\text { factors }\end{array}$ & B & $\begin{array}{c}\text { Standardized } \\
\text { error }\end{array}$ & Beta & t-value & Significant \\
\hline Speed & 0.812 & 0.306 & 0.259 & 2.651 & 0.009 \\
\hline
\end{tabular}

Table 10. Results - Fees / (customer satisfaction)

\begin{tabular}{|l|c|c|c|c|c|}
\hline $\begin{array}{l}\text { E-banking } \\
\text { factors }\end{array}$ & B & $\begin{array}{c}\text { Standardized } \\
\text { error }\end{array}$ & Beta & t-value & Significant \\
\hline Fees & 3.545 & 0.460 & 0.777 & 2.985 & 0.008 \\
\hline
\end{tabular}

Table 11. Results- Customer Satisfaction/Loyalty

\begin{tabular}{|l|c|c|c|c|c|}
\hline $\begin{array}{l}\text { Outcomes of } \\
\text { Satisfaction }\end{array}$ & B & $\begin{array}{c}\text { Standardized } \\
\text { error }\end{array}$ & Beta & t-value & Significant \\
\hline $\begin{array}{l}\text { Customer } \\
\text { Satisfaction }\end{array}$ & 0.125 & 0.047 & 0.261 & 2.680 & 0.009 \\
\hline
\end{tabular}

Table 12. Results-Loyalty/ WOM

\begin{tabular}{|l|c|c|c|c|c|}
\hline $\begin{array}{l}\text { Outcomes of } \\
\text { Satisfaction }\end{array}$ & B & $\begin{array}{c}\text { Standardized } \\
\text { error }\end{array}$ & Beta & t-value & Significant \\
\hline Loyalty & 0.543 & 0.086 & 0.524 & 3.680 & 0.000 \\
\hline
\end{tabular}

Table 13. Results- Customer Satisfaction/WOM

\begin{tabular}{|c|c|c|c|c|c|}
\hline $\begin{array}{c}\text { Outcomes of } \\
\text { Satisfaction }\end{array}$ & B & $\begin{array}{c}\text { Standardized } \\
\text { error }\end{array}$ & Beta & t-value & Significant \\
\hline $\begin{array}{c}\text { Customer } \\
\text { Satisfaction }\end{array}$ & 0.511 & 0.081 & 0.513 & 3.213 & 0.000 \\
\hline
\end{tabular}




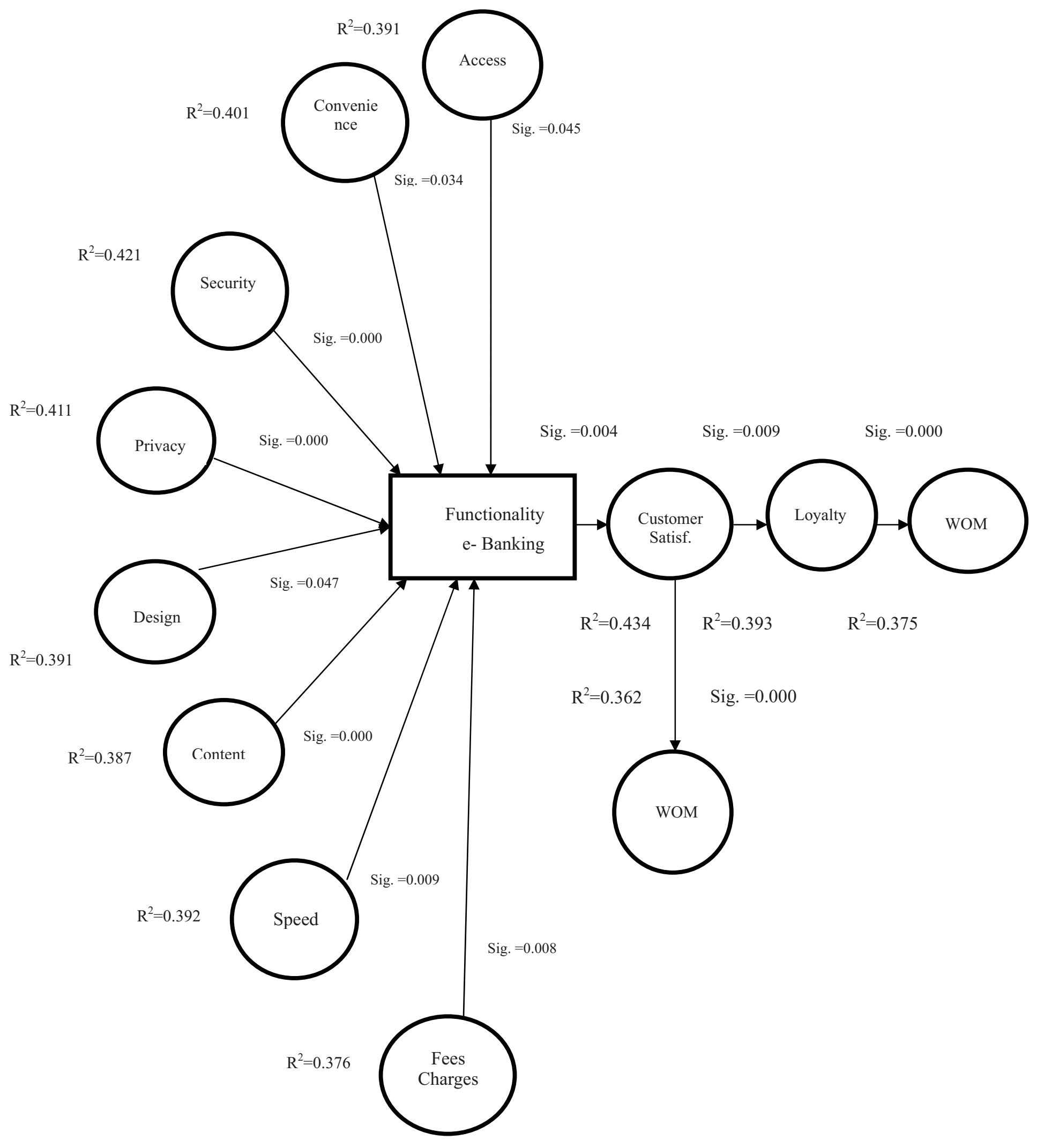

Figure 1. Research Model 